Original Paper http://ajol.info/index.php/ijbcs http://indexmedicus.afro.who.int

\title{
Microbiological analysis of the Cirina forda (Lepidoptera: Saturniidae) commercialized in North Togo
}

\author{
Fègbawè BADANARO ${ }^{*}$, Yao HOEKOU², Koffi Apeti GBOGBO ${ }^{3}$, \\ Komina AMEVOIN ${ }^{4}$ and Kou'santa AMOUZOU ${ }^{1}$
}

${ }^{1}$ Laboratoire de Biochimie Appliquée à la Nutrition et à l'Alimentation, Faculté des Sciences, Université de Lomé, B.P. 1515 Lomé-Togo.

${ }^{2}$ Laboratoire des Sciences Biomédicales, Alimentaires et de Santé Environnementale (LaSBASE), Ecole Supérieure des Techniques Biologiques et Alimentaires (ESTBA), Université de Lomé, B.P. 1515

Lomé-Togo.

${ }^{3}$ Laboratoire de Botanique et Écologie Végétale, Faculté des Sciences, Université de Lomé, B.P. 1515 Lomé-Togo.

${ }^{4}$ Laboratoire d'Entomologie Appliquée, Faculté des Sciences, Université de Lomé, B.P. 1515 Lomé-Togo.

"Corresponding author; E-mail : fbadanar@yahoo.fr ; Tel :00228 90822101

\section{ACKNOWLEDGMENTS}

The authors thank the International Foundation for Science (IFS) for the funding that enabled this work to be carried out.

\begin{tabular}{lll}
\hline Received: 05-10-2020 & Accepted: 20-02-2021 & Published: 28-02-2021 \\
\hline
\end{tabular}

\section{ABSTRACT}

Edible insects are presented as a source of protein, fat and micronutrients. Consequently, they are an attractive growing environment for microorganisms. Although, professionals in this sector in Sub-Saharan Africa use traditional harvesting, processing and marketing techniques, there is little scientific data on the microorganisms that infest edible insects. The aim of this study was to identify the microorganisms present in the Cirina forda supply chain, the most commercially marketed insect species in Togo. A total of 300 samples of fresh, processed and commercial C. forda caterpillars were collected and analyzed using standard microbiological microorganism identification techniques. The caterpillar was $90 \%$ contaminated with Staphylococcus spp, $60 \%$ by Escherichia coli, $40 \%$ by Enterobacter spp, $40 \%$ by Aspergillus niger, $30 \%$ by Klebsiella pneumoniae and $10 \%$ by Mucor spp, Klebsiella oxytoca, Proteus spp, Serratia spp and Aspergillus flavus. Pathogenic microorganisms are found in all samples at all stages of the supply chain, so caterpillars handled using traditional methods are detrimental to the health of the consumer. The presence of germs indicative of contamination of the caterpillar analyzed exposes consumers to the risk of food poisoning.

(c) 2021 International Formulae Group. All rights reserved.

Keywords: Cirina forda, marketing, microorganisms, Togo. 


\section{INTRODUCTION}

Human consumption of insects is a traditional practice in some parts of the world, including Asia, Africa and Latin America. Around 2,086 species of insects are consumed worldwide, across 130 countries and by 3,071 ethnic groups (Ramos-Elorduy, 2009). The United Nations Food and Agriculture Organization (FAO) initiated work in 2008 to promote the consumption of insects as a source of protein, fat and micronutrients (van Huis et al., 2014). According to the FAO, insects are the traditional meals of at least two and a half billion people (van Huis et al., 2014). The most widely eaten insects are beetles (Coleoptera, $28 \%$ ), bees, wasps and ants (Hymenoptera, $21 \%$ ), locusts and crickets (Orthoptera, 16\%), caterpillars (Lepidoptera, 15\%) (Johnson, 2010). Van Huis (2003) notes that in subSaharan Africa, caterpillars (Lepidoptera, $30 \%$ ) are the most widely consumed insects. In addition, specific work has done out on edible caterpillars in Africa. Saturniidae, Notodontidae and Sphingidae are the three major families of Lepidoptera whose caterpillars are most consumed (Malaisse et al., 2003). Saturniidae larvae, especially larger sizes, are very popular in many Africans countries. At the time of their appearance, they are harvested massively. They are highly valued and exported, sub-regionally and to diasporas in Europe (Tabuna, 2000). Among the edible Saturniidae species, the caterpillar Cirina forda is the most accepted food item in Africa: Nigeria, Zambia, Zimbabwe, South Africa, the Central African Republic, the Democratic Republic of Congo, Togo (Yabuda et al., 2019). In Nigeria and Togo in particular, this caterpillar has become the most commercialized insect species (Agbidye et al., 2009; Badanaro et al., 2015). In Togo, the Savannah Region markets of this caterpillar. Although this resource is the subject of a flourishing trade in this region, little research has been done to promote it. Badanaro et al. (2014) have shown that the $C$. forda caterpillar consumed in the Savannah Region of Togo is a good source of protein, fat, fiber and minerals.
However, they are an attractive growing environment for microorganisms. Like other caterpillar species consumed in Togo, C. forda is collected from the ground, while not always respecting hygienic and sanitary conditions. Moreover, it must be recognized that the conservation of caterpillars in Togo (a hot country) is often difficult because of the highly perishable nature of the commodity, the lack of adequate conservation infrastructure and especially the climatic and environmental conditions promoting its rapid degradation. This situation has led to professionals in this sector using traditional techniques for processing and conserving caterpillars. The marketing methods of this caterpillar are also traditional. A large amount of caterpillars is produced each year in Togo. Its production presents very interesting economic and commercial interests, hence the need to promote the $C$. forda sector in Togo. With a view to developing the $C$. forda sector, caterpillars for human consumption sold to consumers must meet the same safety and hygiene standards as all other foods. For this reason, this study aimed at determining the microorganisms carried by the $C$. forda caterpillar throughout its supply chain (from harvesting to the consumer) in order to identify critical factors that may influence the quality of the caterpillar as food item.

\section{MATERIALS AND METHODS Site and study period}

Samples were collected in the village of Malagou (Nano) and at the market in the city of Dapaong in the Savannah Region of Togo during August 2018. The collection and reception equipment consists of $500 \mathrm{ml}$ sterile bottle and a cooler with refrigeration elements. Sterile gloves were used to collect the caterpillars. Fresh and processed caterpillars were collected from shea plants, pickers who are at the same time processors, wholesalers, semi wholesalers, retailers and random consumers. From each source (step), 30 samples of caterpillars were collected. The microbiological analyses were carried out at 
the Laboratory of Biomedical Sciences, Food and Environmental Health (LaSBASE) of the Advanced School of Biological and Food Technology (ESTBA) at the University of Lomé in the same period according to Bawa et al. (2017).

\section{Bacterial culture and identification}

The caterpillars in each group, collected at random, were introduced in a tube containing $10 \mathrm{ml}$ of nutrient broth for the culture of bacteria. The inoculated broth was stirred using a Vortex agitator for 3 minutes to suspend the germs from the caterpillar exoskeleton. The tubes were then incubated at $37{ }^{\circ} \mathrm{C}$ for 3 hours. The culture was then performed on the following agar media: Chapman, Blood Agar, Mac Conkey and Eosin Methylene Blue Agar (EMB). Three petri dishes from each medium were seeded and incubated at $37^{\circ} \mathrm{C}$ for 24 hours. The blood agar petri dishes were incubated in the presence of $5 \% \mathrm{CO}_{2}$. Each type of isolated colonies was then subcultured on the same media in order to obtain pure cultures before the identification tests. The identification of bacteria was based on the study of their biochemical characteristics. After controlling Gram coloration, the search for catalase and coagulase was performed on Gram-positive cocci. From the EMB and Mac Conkey media, a classic enterobacteriaceae identification gallery composed of Simmons' Citrate, KliglerHajna, Mannitol-mobility and Indole Urea media was seeded on each isolated colony to identify Gram-negative bacilli. All the galleries were incubated at $37^{\circ} \mathrm{C}$ for 18 to 24 hours. The galleries were read after incubation and then the bacillus were identified using the dichotomous enterobacteriaceae identification table. In addition to these tests, the oxidase test was conducted on Gram-negative bacillus that did not ferment glucose.

\section{Fungi culture and identification}

Fungi were isolated from caterpillar lots collected at each stage by direct contact on
Potato Dextrose Agar (PDA) and Sabouraud chloramphenicol. The fungi isolation technique is as follows: 2 caterpillars were randomly selected and placed on the surface of the agar. Three petri dishes were seeded in groups and incubated at $25{ }^{\circ} \mathrm{C}$ for 7 days. The plates were observed after 72 hours and then after 7 days. When the culture is positive, subculture was done on the PDA agar for pure culture before identification. The identification was based on macroscopic and microscopic examinations. The macroscopic examination involved identifying the characteristics visible to the naked eye: the appearance of the mycelium, its colour on the front and back. Microscopic examination of the fungi was carried out by using lactophenol blue cotton. The identification was done by referring to Barnett. (1967) and Botton et al. (1990).

\section{Data processing}

All tests were carried out in triplicate. The data was processed using the Excel 2013 spreadsheet $\odot$.

\section{RESULTS}

The isolated germs at different steps of the C. forda supply chain are presented in Table 1. The results of the microbiological analysis of the $C$. forda samples show that the caterpillars were contaminated. Staphylococcus spp (80\%) was found in the majority of samples analyzed, followed by Escherichia coli (60\%). Aspergillus niger (40\%), Klebsiella pneumoniae (30\%), Enterobacter spp (20\%), Enterobacter aerogenes (20\%), Klebsiella oxytoca (10\%), Proteus spp (10\%), Serratia spp (10\%), Mucor spp (10\%), Staphylococcus aureus (10\%) and Aspergillus flavus (10\%) were also found in the samples (Figure 1). Table 2 shows the contamination rates of $C$. forda at different stages of the supply chain. The highest contamination rates are recorded for harvest stages and marketing ranged from 50 to $100 \%$. Contamination rates in the processing stages are relatively lower (less than 50\%). 
Table 1: Isolated Germs at different steps of the $C$. forda supply chain.

\begin{tabular}{ll}
\hline Steps & Isolated germs \\
\hline 1. Caterpillars sampled at the site & $\begin{array}{l}\text { Staphylococcus spp, Escherichia coli, Enterobacter aerogenes, } \\
\text { Aspergillus niger }\end{array}$ \\
2. Fresh caterpillars sampled from Pickers & $\begin{array}{l}\text { Staphylococcus spp, Klebsiella oxytoca, Enterobacter spp, } \\
\text { Aspergillus niger }\end{array}$ \\
$\begin{array}{ll}\text { 3. Caterpillars sampled after boiling by pickers } \\
\text { 4. Caterpillars sampled after boiling and drying }\end{array}$ & $\begin{array}{l}\text { Staphylococcus spp, Escherichia coli, Klebsiella pneumoniae } \\
\text { 5. Caterpillars sampled after roasting }\end{array}$ \\
6. Caterpillars sampled after roasting and & Staphylococcus spp, Klebsiella pneumoniae \\
drying & Staphylococcus aureus, Escherichia coli, Enterobacter spp, \\
7. Caterpillars purchased from producers & Pseudomonas spp, Aspergillus niger, Mucor spp \\
8. Caterpillars purchased from wholesalers & Staphylococcus spp, Proteus spp, Escherichia coli \\
9. Caterpillars purchased from semi- & Enterobacter aerogenes, Escherichia coli, Pseudomonas spp \\
wholesalers & Staphylococcus spp, Klebsiella pneumoniae, Serratia spp, \\
10. Caterpillars purchased from retailers & Aspergillus niger, Aspergillus flavus \\
\hline
\end{tabular}

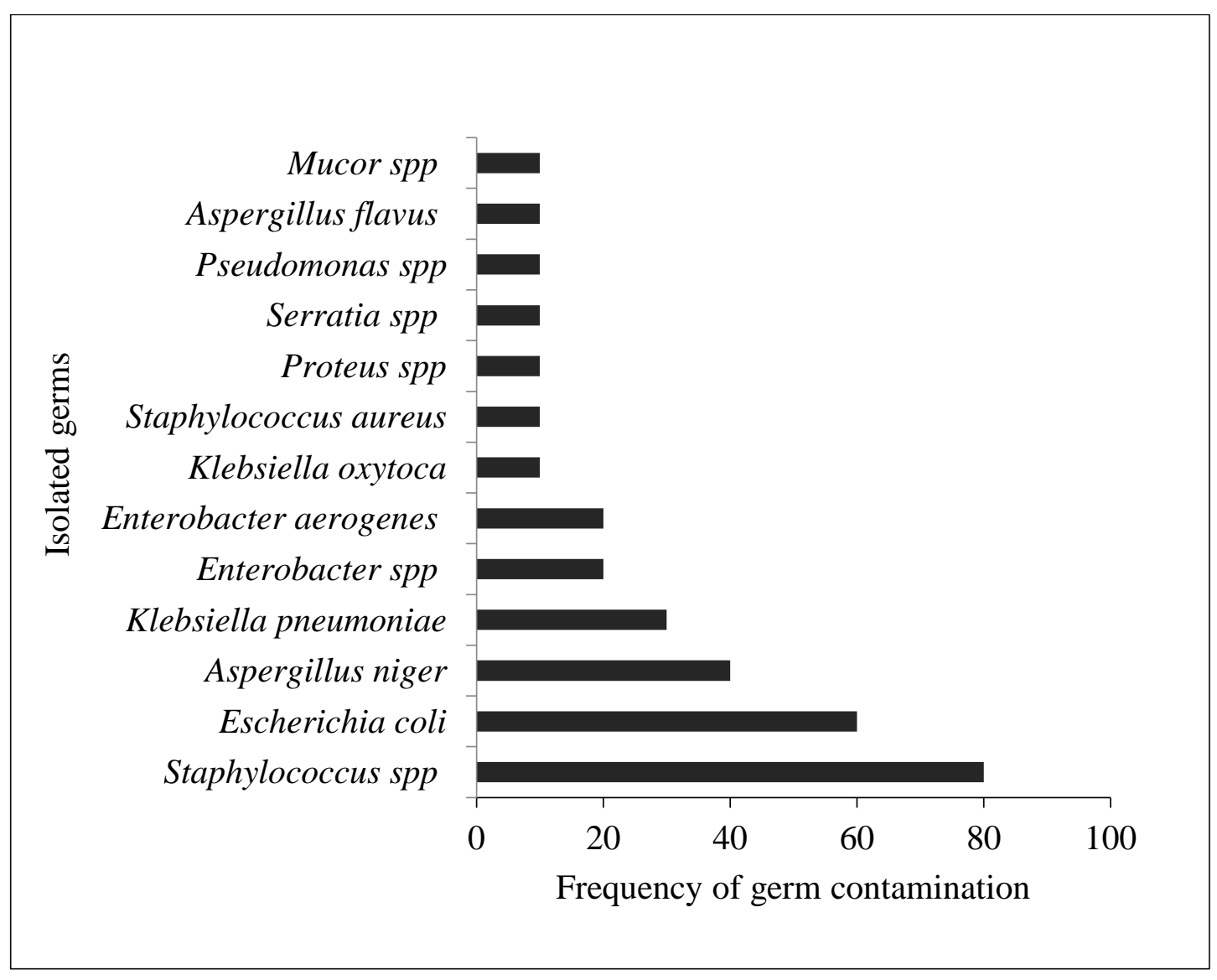

Figure 1: Frequency of contamination of caterpillars by isolated germs. 
Table 2: Contamination rate (\%) at the different steps of the $C$. forda supply chain ( $\mathrm{n}=30$ per step)

\begin{tabular}{lcccccccccc}
\hline Steps & 1 & 2 & 3 & 4 & 5 & 6 & 7 & 8 & 9 & 10 \\
\hline Number of positive samples & 22 & 22 & 15 & 10 & 10 & 14 & 30 & 15 & 14 & 17 \\
Contamination rate (\%) & 73.3 & 73.3 & 50 & 33.3 & 33.3 & 46.6 & 100 & 50 & 46.6 & 56.6 \\
\hline
\end{tabular}

\section{DISCUSSION}

Like any animal, insects are not immune from diseases caused by bacteria, viruses and fungi (Dillon and Charnley, 2002; Vega and Kaya, 2012). However, insect pathogenic microorganisms sometimes belong to taxonomic groups different from those of humans. They have an entirely different life cycle from human microorganisms and would pose no danger to humans (van Huis, 2013). In the genus Bacillus, the pathogen of the insects Bacillus thuringiensis and that of the vertebrates Bacillus anthracis appear to have totally different life cycles. B. thuringiensis is a pathogen in insects but is harmless in humans (van Huis, 2013). Indeed, because insects are taxonomic much further from humans than livestock; they may be thought to be at low risk of transmission of zoonoses such as avian influenza H1N1 and mad cow disease (bovine spongiform encephalopathy). On the other hand, pathogenic microorganisms can cause disease in humans or produce toxins that can proliferate on insects if hygiene measures are insufficient during the supply, processing and marketing processes (Johnson, 2010). According to this study, the microorganisms are carried by the caterpillar C. forda throughout the chain (from the site to the consumer). The caterpillars are more infested for at the collection and marketing stages than during processing. Reducing the microbial load during caterpillar processing demonstrates that the processing methods used are effective in reducing initial contamination. The increase in microbial load during the marketing of the caterpillar after transformation would be due to the lack of hygiene in the handling of the caterpillar. Factors contributing to the increased potential risks to the caterpillar along the marketing chain appear to be inadequate hygiene at all stages of the commercial chain, such as inadequate or unsuitable storage conditions and exposure to air. The results of this study corroborate those of other studies on edible insects in Africa. In Nigeria, pathogenic bacteria including $S$. aureus, $P$. aeruginosa and B. cereus were isolated from Oryctes monoceros (Coleoptera: Scarabaeidae) that was partially dried, fried and sold in markets (Banjo et al., 2006). The C. forda samples studied are contaminated in the collection environment by several pathogenic microorganisms including Staphylococcus spp, E. coli, E. aerogenes and A. niger. Therefore, the products upstream of the sector are not of good quality. The infestation of caterpillars could come from the collection environment as the caterpillars are collected from the wild by villagers whose household waste is released in the environment and who do not have latrines. However, our study did not focus on the remediation of the caterpillar collection medium. Contamination of caterpillars could also be caused by inadequate collection practices. Furthermore, this study shows that samples are contaminated in $90 \%$ of cases with Staphylococcus and 60\% of cases with E. coli. Of the germs found, Staphylococcus spp is the most represented. Its presence is evidence of poor hygiene (Sandel and McKillip, 2004; De Buyser and Sutra, 2005). S. aureus found in the samples is a bacterium that causes common skin-mucous infections such as panaris, boils, and various abscesses (De Buyser and Sutra, 2005). E. coli is the species that comes second in terms of representation. As E. coli is a common presence in human and animal guts, it is sought as a germ that controls fecal contamination. The presence of fecal contamination-indicator germs in the samples analyzed exposes consumers to the risk of gastroenteritis (HCSP, 2015 ; Ouendo et al., 2015). E. coli infection can cause serious food borne illnesses such as abdominal cramps and diarrhea, which in some cases progress to bloody diarrhea (Ahoyo et al., 2010). There may also be fever and vomiting (EFSA, 2007). 
Other pathogenic germs like Enterobacter spp, K. pneumoniae, K. oxytoca and Proteus spp found in the samples are responsible for urinary tract and other infections (Toudji et al., 2017 ; Yandai et al., 2019). The fungi detected in the samples of the caterpillars studied are Aspergillus niger A. favus and Mucor spp, species can cause fungal infections (Halewyn et al., 2002). As a result, caterpillars are contaminated with pathogens. Their consumption can lead to ingestion of pathogens that cause food borne illnesses.

\section{Conclusion}

The caterpillars in the $C$. forda sector in north Togo do not appear to be produced according to good collection, processing and, above all, marketing practices. Pathogenic microorganisms are found in all steps throughout the $C$. forda supply chain. The increasing spread of insect-based diet is accompanied by risks in terms of microbiological quality.

\section{COMPETING INTERESTS}

The authors have declared that there is no competing interest.

\section{AUTHORS' CONTRIBUTIONS}

This work was carried out in collaboration between all authors. FB, KA and KSA designed the project; $\mathrm{BF}$ carried out the sampling; $\mathrm{BF}$ and $\mathrm{YH}$ carried out the experiments; $\mathrm{FB}$ and $\mathrm{YH}$ analyzed the data; $\mathrm{BF}, \mathrm{YH}$ and KAG wrote the manuscript; AK oversaw all activities; all authors agreed to the final version of the manuscript and its publication.

\section{ACKNOWLEDGMENTS}

The authors thank Dr Wilson-Bahun Tetevi for his help in producing the English version of this manuscript.

\section{REFERENCES}

Agbidye FS, Ofuya TI, Akindele SO. 2009. Some Edible Insect Species Consumed by the People of Benue State, Nigeria. Pakistan Journal of Nutrition, 8: 946950. DOI: 10.3923/pjn.2009.946.950

Ahoyo TA, Ahissou H, Kounon F, Aminou T, Dramane K. 2010. Etude de la qualité bactériologique des aliments vendus sur le campus de l'Université d'Abomey Calavi au Bénin. Int. J. Biol. Chem. Sci., 4(4): 1083-1092.

Badanaro F, Amevoin K, Lamboni C, Amouzou K. 2014. Edible Cirina forda (Westwood, 1849) (Lepidoptera: Saturniidae) caterpillar among Moba people of the Savannah Region in North Togo: from collector to consumer. Asian J. Appl. Sc. Eng., 3: 13-24. DOI: 10.15590/ajase/2014/v3i8/54479

Badanaro F, Amévoin K, Sanbena Banibea B, Amouzou K. 2015. Les insectes comestibles au Togo : diversité et potentiel économique. Actes du Colloque Scientifique International de l'Université de Kara, 1 : 465-512.

Banjo AD, Lawal OA, Adeyemi AI. 2006. The microbial fauna associated with the larvae of Oryctes monoceros. Journal of Applied Sciences Research, 2(11): 837843.

Barnett HL. 1967. Illustrated Genera of Imperfect Fungi. Burgess Publishing Co: Minneapolis.

Bawa RA, Gbogbo KA, Hoekou YP, Mollong E, Nuto Y, Glitho IA. 2017. Bactéries et moisissures associées à Musca domestica L. et à Chrysomya chloropyga Wied. (Diptera : Muscomorpha) collectées sur deux sites à environnements différents de la ville de Lomé. Journal of Applied Biosciences, 120 : 12027-12035. DOI: https://dx.doi.org/10.4314/jab.v120i1.5

Botton B, Breton A, Fèvre M, Gauthier S, Guy P, Larpent JP, Reymond P, Sanglier JJ, Vayssier Y, Veau P. 1990. Moisissures Utiles et Nuisibles, Importance Industrielle. Edn Masson : Paris.

De Buyser ML, Sutra L. 2005. Staphylococcus aureus. In Bactériologie Alimentaire Compendium d'Hygiène des Aliments, Federighi M (ed). Economica : Paris ; 25-51.

Dillon RJ, Charnley K. 2002. Mutualism between the desert locust Schistocerca gregaria and its gut microbiota. Research in Microbiology, 153: 503509. DOI: $\quad 10.1016 / \mathrm{s} 0923-$ 2508(02)01361-X 
EFSA (European Food Safety Authority). 2007. Scientific Opinion of the Panel on Biological Hazards on a request from EFSA on monitoring of verotoxigenic Escherichia coli (VTEC) and identification of human pathogenic VTEC types. EFSA Journal, 579: 1-61. DOI : 10.2903/j.efsa.2007.579

Halewyn MA, Leclerc JM, King N, Bélanger M, Legris, M, Frenette Y. 2002. Les risques à la santé associés à la présence de moisissures en milieu intérieur. Document synthèse. Québec.

HCSP (Haut Conseil de la Santé Publique). 2015. Gastroentérites à Escherichia coli Entérohémorragique. Conduite à Tenir. Collection Avis et Rapports : Paris.

Johnson DV. 2010. The contribution of edible insects to human nutrition and to forest management. In Forest Insects as Food: Humans Bite Back, Durst PB, Johnson DV, Leslie RN, Shono K (Eds). Proceedings of a workshop on AsiaPacific resources and their potential for food development : Bangkok ; 5-22.

Ouendo E-M, Saizonou J, Degbey C, Glele Kakai C, Glele Y, Makoutode M. 2015. Gestion du risque infectieux associé aux soins et services au Centre National Hospitalier et Universitaire Hubert Koutoukou Maga de Cotonou (Bénin). Int. J. Biol. Chem. Sci., 9(1): 292-300. DOI:

http://dx.doi.org/10.4314/ijbcs.v9i1.26.

Ramos-Elorduy J. 2009. Anthropoentomophagy: Cultures, evolution and sustainability. Entomological Research, 39(5): 271-288. DOI: https://doi.org/10.1111/j.17485967.2009.00238.x

Sandel MK, Mckillip JL. 2004. Virulence and recovery of Staphylococcus aureus relevant to the food industry using improvements on traditional approaches. Food Control, 15: 5-10. DOI : 10.1016/S0956-7135(02)00150-0

Tabuna H. 2000. Les produits forestiers non ligneux alimentaires de l'Afrique
Centrale sur les marchés français et belges : situation actuelle et perspectives. Ecole doctorale Sciences de la nature et l'homme, Paris, p.226

Toudji AG, Djeri B, Karou DS, Tigossou S, Ameyapoh Y, De Souza C. 2017. Prévalence des souches d'entérobactéries productrices de bêtalactamases à spectre élargi isolées au Togo et de leur sensibilité aux antibiotiques. Int. J. Biol. Chem. Sci., 11(3): $\quad 1165-1177 . \quad$ DOI: https://dx.doi.org/10.4314/ijbcs.v11i3.1 9

Van Huis A. 2003. Insects as food in Subsaharan Africa. Insect Sci. Applic., 23(3): 163-185. DOI: https://doi.org/10.1017/S17427584000 23572

Van Huis A. 2013. Potential of insects as food and feed in assuring food security. Annual review of Entomology, 58(1): 563-583. DOI : 10.1146 / annurev-ento120811-153704

Van Huis A, Joost Van Itterbeeck J, Klunder H, Mertens E, Halloran A Muir G, Vantomme P. 2014. Edible insects. Future prospects for food and feed security. FAO forestry paper, Rome.

Vega F, Kaya H. 2012. Insect Pathology. Academic Press: Londres.

Yabuda KH, Mbembo B M, Bongo G N, Gbendo TG, Tshil FM, Kogba LS, Ngbolua K. 2019. Contribution to the ecological study of edible caterpillars in GbadoLite city and its surroundings, Nord-Ubangi, Democratic Republic of the Congo. Plants and Environment, 1(2): $\quad 109-114 . \quad$ DOI: 10.5281/zenodo.999756

Yandai FH, Ndoutamia G, Nadlaou B, Barro N. 2019. Prevalence and resistance profile of Escherichia coli and Klebsiella pneumoniae isolated from urinary tract infections in N'Djamena, Tchad. Int. J. Biol. Chem. Sci., 13(4): 2065-2073. DOI: https://dx.doi.org/10.4314/ijbcs.v13i4.1 3. 